\section{Inconsistency between supplement and article?}

In their recent article in the Annals of the Rheumatic Diseases, van der Heijde $\mathrm{D}$ et $a l^{1}$ evaluated the effect of certolizumab pegol (CZP) on radiographic progression in patients with ankylosing spondylitis and non-radiographic axial spondyloarthritis (nr-axSpA). They suggested that CZP-treated patients with axSpA had less modified Stokes Ankylosing Spondylitis Spinal Score (mSASSS) change and spinal progression at the end of 4 years. I read this fascinating article with interest. There is not an extra word to say about the design of the study, data presentation and valuable conclusion. But I noticed a conflict between table 1 (supplementary table 1 ) and supplementary table 2 .

According to results of the study, there are 196 patients who had $\geq 1 \mathrm{mSASSS}$ assessment, which is consistent with Supplementary table 2. But, according to table 1 and Supplementary table 1 of the study, there are 190 patients who have baseline mSASSS assessment, which is inconsistent with supplementary table 2. According to supplementary table 2, there is 193 patient who have baseline mSASSS assessment. I did not notice any explanation of this situation in the article. Although I am aware that three patients would not change the results of the study, I think this should be clarified.

\section{Hakan Babaoglu}

Department of Internal Medicine, Division of Rheumatology, Gazi University Faculty of Medicine, Ankara, Turkey
Correspondence to Dr Hakan Babaoglu, Gazi University Hospital, Ankara 06560, Turkey; hakanbabaoglu@gmail.com

Competing interests None declared.

Patient consent Not required.

Provenance and peer review Not commissioned; internally peer reviewed.

(c) Article author(s) (or their employer(s) unless otherwise stated in the text of the article) 2019. All rights reserved. No commercial use is permitted unless otherwise expressly granted.

\section{Check for updates}

To cite Babaoglu H. Ann Rheum Dis 2019;78:e84.

Received 29 May 2018

Accepted 5 June 2018

Published Online First 19 June 2018

\section{Linked}

http://dx.doi.org/10.1136/annrheumdis-2018-213887

Ann Rheum Dis 2019;78:e84. doi:10.1136/annrheumdis-2018-213844

\section{REFERENCE}

1 van der Heijde D, Baraliakos X, Hermann KA, et al. Limited radiographic progression and sustained reductions in MRI inflammation in patients with axial spondyloarthritis: 4-year imaging outcomes from the RAPID-axSpA phase III randomised trial. Ann Rheum Dis 2018;77:699-705. 